\title{
Changes in circulating and ovarian concentrations of bioactive tumour necrosis factor $\alpha$ during the first ovulation at puberty in rats and in gonadotrophin-treated immature rats
}

\author{
V. Montgomery Rice ${ }^{1}$, S. D. Limback ${ }^{2}$, K. F. Roby ${ }^{3}$ and \\ P. F. Terranova ${ }^{1,2 *}$ \\ ${ }^{1}$ Department of Obstetrics and Gynecology, ${ }^{2}$ Department of Physiology, and ${ }^{3}$ Department of Anatomy and \\ Cell Biology, Center for Reproductive Sciences, University of Kansas Medical Center, Kansas City, \\ KS 66160-7401, USA
}

Tumour necrosis factor $\alpha$ (TNF- $\alpha$ ) concentrations were measured during periods of controlled and natural follicular development and ovulation in rat ovaries. Concentrations of bioactive TNF- $\alpha$ were determined in the ovaries and sera of rats during puberty (the period of vaginal opening and the first ovulation) and in immature rats after gonadotrophin treatment. Ovaries and sera were collected from 33-, 35-, 37-, 39-, 41- and 43-day-old rats ( $n=6$ or 7 per group); vaginal opening occurs on day 35 . The presence of ovarian follicles and corpora lutea or ova in the oviducts was assessed. For gonadotrophin treatment, a single subcutaneous injection of 5 iu equine chorionic gonadotrophin (eCG) was administered at $08: 00 \mathrm{~h}$ to 28 -day-old rats to stimulate follicular development. A single subcutaneous injection of 10 iu human chorionic gonadotrophin (hCG) was administered $48 \mathrm{~h}$ later to induce ovulation. Ovaries and sera from three to six animals per group were collected $0,3,24,48,51,54,57,60$ and $72 \mathrm{~h}$ after injection of eCG. At puberty, ovarian concentrations of TNF- $\alpha$ were highest (approximately $1.1 \mathrm{fg} \mu \mathrm{g}^{-1}$ ovarian protein) before vaginal opening and the first ovulation. After vaginal opening and ovulation at day 37 ,

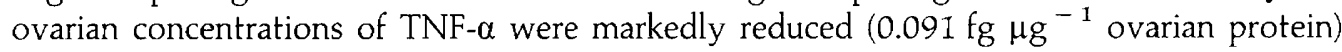
and remained low up to day 43. Serum concentrations of TNF- $\alpha$ remained low throughout the period of vaginal opening and the first ovulation $\left(8-32 \mathrm{pg} \mathrm{ml}^{-1}\right)$. In 43-day-old rats serum concentrations of TNF- $\alpha$ increased $\left(105 \mathrm{pg} \mathrm{ml}^{-1}\right)$. In the immature ovaries of 28-day-old rats TNF- $\alpha$ concentrations were highest before injection of eCG (approximately

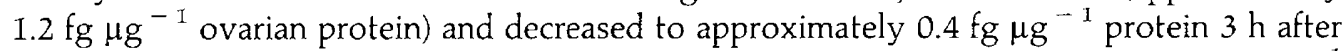
injection. TNF- $\alpha$ concentrations decreased further $24 \mathrm{~h}$ after eCG injection $\left(<0.1 \mathrm{fg} \mathrm{hg}^{-1}\right.$ protein) and remained low until $48 \mathrm{~h}$ after eCG injection. Serum concentrations of TNF- $\alpha$ did not change during the $48 \mathrm{~h}$ period after injection of eCG. hCG was administered $48 \mathrm{~h}$ after eCG, and ovarian and serum TNF- $\alpha$ concentrations increased transiently. Serum TNF- $\alpha$ concentrations increased $3 \mathrm{~h}$ after hCG and remained elevated until $9 \mathrm{~h}$ after injection, after which concentrations decreased. Ovarian concentrations of TNF- $\alpha$ increased $6 \mathrm{~h}$ after hCG, peaked (approximately $0.5 \mathrm{fg} \mu \mathrm{g}^{-1}$ protein), and then declined. These results indicate that during puberty and the first ovulation, circulating and ovarian TNF- $\alpha$ concentrations change. In addition, exogenous gonadotrophins alter circulating and ovarian TNF- $\alpha$ concentrations. These data suggest that TNF- $\alpha$ has a role in follicular development and ovulation during puberty and in immature rats treated with gonadotrophins to induce ovulation.

\section{Introduction}

Previous studies have revealed that the ovary contains TNF- $\alpha$ and that oocytes, granulosa cells, luteal cells, endothelial cells

* Correspondence.

Received 10 November 1997. and macrophages are specific sites of TNF- $\alpha$ localization (Terranova et al, 1995). Previous studies have shown that the TNF- $\alpha$ is present in the corpora lutea of cattle (Shaw and Britt, 1995) and pigs (Wuttke et al., 1993; Hehnke-Vagnoni et al., 1995), and that TNF- $\alpha$ increases in corpora lutea after the onset of luteal regression in cows (Shaw and Britt, 1995) and sheep (Ji et al., 1991). During luteal regression in cows, serum 
concentrations of TNF- $\alpha$ do not change (Shaw and Britt, 1995). In rats, TNF- $\alpha$ bioactivity is low but detectable in perfusion medium of ovulating ovaries $5 \mathrm{~h}$ after perfusion (Brannstrom et al., 1994). However, to date there have been no reports of changes in ovarian or serum concentrations of TNF- $\alpha$ during the first natural ovulation or after administration of gonadotrophins to induce follicular development and ovulation. Therefore, the aim of this study was to determine the effects of the onset of puberty and the first natural ovulation on ovarian and circulating concentrations of TNF- $\alpha$. In addition, the effects of ovulation induction by exogenous equine eCG and hCG on ovarian and circulating TNF- $\alpha$ concentrations in immature rats were determined.

\section{Materials and Methods}

Sprague Dawley rats (21-day-old) were obtained from Harlan Inc. (Indianapolis, IN) and vaginal opening was assessed once a day from day 26. Vaginal opening, which is an indicator of puberty, occurs in approximately 35-day-old animals. Ovaries were collected at 09:00 $\mathrm{h}$ from 33-, 35-, 37-, 39-, 41- and 43-day-old rats throughout puberty. Rats were decapitated and serum and ovaries were collected under aseptic conditions. Ovaries were cleaned and the presence and developmental condition of large follicles or corpora lutea were assessed under a dissecting microscope. Oviducts were flushed with saline and the number of ova was counted. Animals examined on day 35 had not ovulated although vaginal opening had occurred in most. All animals examined on day 37 had ova present in the oviducts indicating ovulation had occurred on day 36 or the morning of day 37.

An injection of 5 iu eCG (Sigma Chemical Co, St Louis, MO) in $0.1 \mathrm{ml} \mathrm{PBS}$ was administered s.c. at 08:00 h to 28-day-old female rats in order to stimulate follicular development. Rats were decapitated and serum and ovaries were collected under aseptic conditions $0,3,24,48,51,54,57,60$ and $72 \mathrm{~h}$ after injection. A single injection of $10 \mathrm{iu}$ hCG was administered $48 \mathrm{~h}$ after injection of eCG to induce ovulation. Controls were injected with $0.1 \mathrm{ml}$ PBS using the same schedule as for the eCG and hCG injections.

Ovaries and sera were collected from approximately six animals at each time point in the natural and eCG-stimulated cycles. Ovarian homogenates were prepared and stored at $-20^{\circ} \mathrm{C}$ until assayed for TNF- $\alpha$. Blood was allowed to clot overnight at $4^{\circ} \mathrm{C}$. The serum was then removed, centrifuged (1900 $\mathrm{g}$ for $20 \mathrm{~min}$ ) to remove red blood cells, and stored at $-20^{\circ} \mathrm{C}$ until assayed for TNF- $\alpha$. All TNF- $\alpha$ samples from a given experiment were assayed in the same assay and after only one thaw. Animal studies were in accordance with the Institutional Animal Care and Use Committee guidelines.

\section{L929 TNF-a bioassay}

TNF- $\alpha$ bioactivity was determined by the ability to lyse actinomycin D-treated mouse L929 cells (CCL1 from American Type Culture Collection) (Mosmann, 1983). The number of viable cells was quantified by the colorimetric method using $1 \mathrm{mg}$ 3-(4,5-dimethylthiaszol-2-yl)-2,5-diphenyl tetrazolium bromide $\mathrm{ml}^{-1}(\mathrm{MTT})$, a yellow substrate which is converted to a blue product by mitochondrial enzymes that are only active in viable cells. The method used was as described Marcinkiewicz et al. (1994). Briefly, 40000 cells per well in $100 \mu \mathrm{l}$ medium (RPMI 1640, Sigma, St Louis, MO, containing $10 \%$ heat inactivated fetal bovine serum, $25 \mathrm{mmol}$ Hepes $\mathrm{I}^{-1}$, 50 units penicillin $\mathrm{ml}^{-1}$, and $50 \mu \mathrm{g}$ streptomycin $\mathrm{ml}^{-1}$ ) were added to 96-well flat-bottomed culture dishes. Standard TNF- $\alpha$ and samples were then added. After $16 \mathrm{~h}$ incubation at $37^{\circ} \mathrm{C}$ in $5 \% \mathrm{CO}_{2}$ and air, cell numbers were determined by $3 \mathrm{~h}$ incubation in MTT. The standard curve ranged from 0.1 to $10 \mathrm{pg} \mathrm{ml}{ }^{-1}$. Recombinant rat TNF- $\alpha$ was obtained from Genzyme Inc. (Cambridge, MA) and had an activity of $5 \times 10^{7}$ units $\mathrm{mg}^{-1}$. Each ovary was placed in $200 \mu \mathrm{l}$ medium and homogenized for $20 \mathrm{~s}$ at room temperature to prepare the tissue for bioassay. The homogenate was then centrifuged at $10000 \mathrm{~g}$ for $10 \mathrm{~min}$. Supernatant fluid was collected and stored at $-20^{\circ} \mathrm{C}$. Validation of the TNF- $\alpha$ bioassay for rat sera and ovaries was performed on selected samples by neutralizing TNF- $\alpha$ bioactivity with a polyclonal antibody to human TNF- $\alpha$ previously shown to crossreact with rat TNF- $\alpha$ (Sancho-Tello et al., 1993).

\section{Protein assay}

Protein assay was carried out according to the method of Bradford (1976).

\section{Statistical analysis}

Data were analysed by one way analysis of variance followed by Fisher's protected least significant difference test (Statview $512^{+}$, Agoura Hills, CA). Differences were considered significant if $P<0.05$.

\section{Results}

\section{Ovarian TNF-a}

Puberty and the first ovulation. Ovarian concentrations of TNF- $\alpha$ were highest (approximately I fg $\mu \mathrm{g}^{-1}$ ovarian protein) before vaginal opening and the first ovulation at puberty (Fig. I). After the first ovulation (day 37; ova present in oviducts) ovarian concentrations of bioactive TNF- $\alpha$ were markedly reduced $\left(0.09 \mathrm{fg} \mu \mathrm{g}^{-1}\right.$ ovarian protein). Ovarian concentrations of TNF- $\alpha$ remained low during the 8 days after the first ovulation (Fig. 1).

eCG stimulation. Ovarian concentrations of TNF- $\alpha$ were highest (approximately $1.2 \mathrm{fg} \mathrm{\mu g}^{-1}$ ovarian protein) before injection of eCG (Fig. 2). TNF- $\alpha$ concentrations declined to approximately $0.4 \mathrm{fg} \mu \mathrm{g}^{-1}$ protein $3 \mathrm{~h}$ after $\mathrm{eCG}$ and decreased further to $<0.1 \mathrm{fg}_{\mu \mathrm{g}}{ }^{-1}$ protein $24 \mathrm{~h}$ after injection. Ovarian TNF- $\alpha$ concentrations remained low up to $48 \mathrm{~h}$ after eCG. hCG was administered $48 \mathrm{~h}$ after eCG and ovarian concentrations of TNF- $\alpha$ increased gradually to a peak (approximately $0.5 \mathrm{fg} \mathrm{\mu g}^{-1}$ protein) $6 \mathrm{~h}$ after $\mathrm{hCG}$, and then declined. Ovarian TNF- $\alpha$ concentrations $24 \mathrm{~h}$ after hCG were higher compared with values directly before injection with 
hCG (Fig. 2). TNF- $\alpha$ concentrations in the ovaries of salineinjected control animals did not show the same changes as the eCG and hCG-treated animals (Table 1). TNF- $\alpha$ concentrations in 29-, 30- and 31-day-old control animals were not different
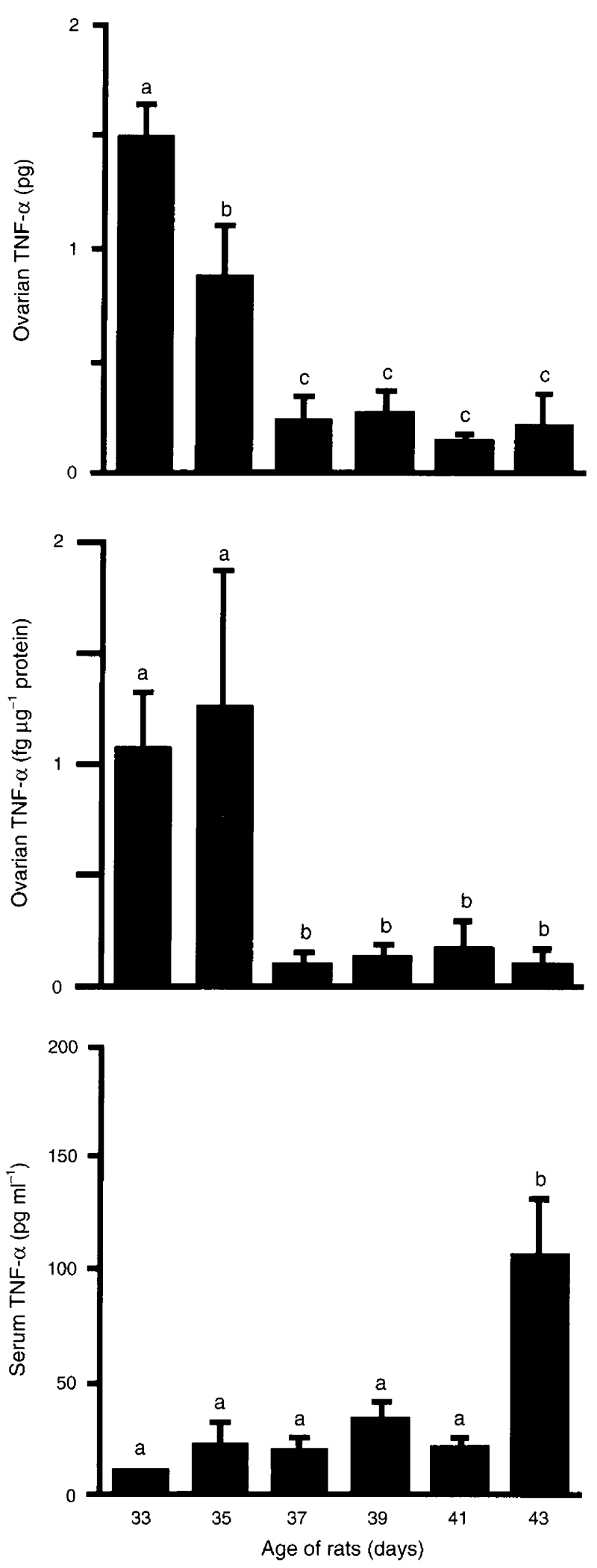

from those in 28-day-old experimental animals before injection of eCG.

\section{Serum TNF-a}

Puberty and the first ovulation. Serum concentrations of TNF- $\alpha$ before and after vaginal opening and the first ovulation did not vary (33-41-day-old animals) (Fig. 1). However, in 43 -day-old animals serum TNF- $\alpha$ concentrations increased.

$e C G$ stimulation. Serum concentrations of TNF- $\alpha$ did not change during $48 \mathrm{~h}$ after injection with eCG (Fig. 2). However, serum concentrations of TNF- $\alpha$ increased $3 \mathrm{~h}$ after hCG when compared with pre-hCG values at 0,3 and 24 h. However, in contrast to ovarian TNF- $\alpha$, serum concentrations of TNF- $\alpha$ remained elevated until $9 \mathrm{~h}$ after $\mathrm{hCG}$ and then decreased (Fig. 2).

\section{Discussion}

This is the first demonstration of alterations in ovarian TNF- $\alpha$ concentrations in vivo. Ovarian concentrations of TNF- $\alpha$ varied at puberty and in response to exogenous gonadotrophins. Ovarian TNF- $\alpha$ concentrations were highest in immature ovaries of 28-day-old rats before injection of eCG and in 33-day-old rats just before vaginal opening and the first ovulation (28-day-old: $1.1 \pm 0.256 \mathrm{fg}$ TNF- $\alpha \mu \mathrm{g}^{-1}$ protein; 33-day-old: $1.054 \pm 0.262 \mathrm{fg}$ TNF- $\alpha \mu \mathrm{g}^{-1}$ protein). Within $3 \mathrm{~h}$ after injection of eCG, ovarian TNF- $\alpha$ concentrations declined rapidly and reached the lowest value $24 \mathrm{~h}$ after eCG. In the first natural cycle TNF- $\alpha$ concentrations did not decline until after ovulation. The physiological significance of the decline in TNF- $\alpha$ may be related to increased ovarian cAMP. The initial injection of eCG may be similar to the primary surge in $\mathrm{LH}$ that initiates the first ovulation and stimulates an increase in ovarian cAMP concentration (Richards, 1980). Phosphodiesterase inhibitors elevate cAMP and are potent inhibitors of transcription of TNF- $\alpha$ (Doherty et al., 1991). Since TNF- $\alpha$ has a modulatory role in follicular development and steroidogenesis (Sancho-Tello et al., 1993; Terranova et al., 1995), it can be hypothesized that elevated concentrations of ovarian cAMP stimulate follicular development by inhibiting the secretion of TNF- $\alpha$. Sancho-Tello et al. (1993) reported that endotoxin, which increases circulating concentrations of TNF- $\alpha$ by activating macrophages, inhibits the responsiveness of the immature ovary to eCG and hCG as evidenced by reduced oestradiol secretion and a decrease in the number of ova shed. Administration of polyclonal antisera to recombinant TNF- $\alpha$ results in oestradiol concentrations and numbers of ova similar to those

Fig. 1. Ovarian and serum concentrations of tumour necrosis factor $\alpha$ (TNF- $\alpha$ ) during puberty and the first ovulation in rats. Ovaries and sera were collected from 33-, 35-, 37-, 39-, 41- and 43-day-old rats. Vaginal opening occurs at approximately day 35 and the first ovulation occurs 1 or 2 days after vaginal opening. $n=6$ in all groups except for 39- and 41-day-old groups $(n=7)$. Bars with different letters are significantly different $(P<0.05)$ by Fisher's protected least significant difference test. 

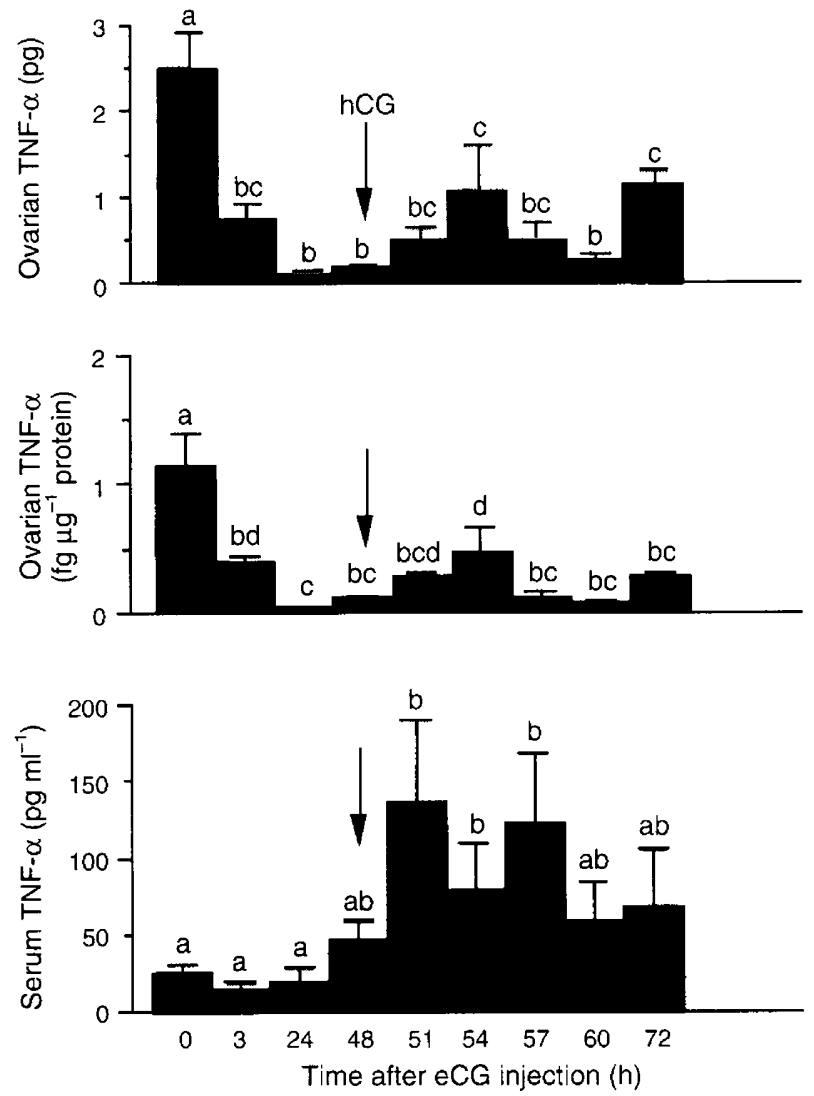

Fig. 2. Ovarian and serum concentrations of tumour necrosis factor $\alpha$ (TNF- $\alpha$ ) in equine chorionic gonadotrophin (eCG)-treated immature rats. A 5 iu injection of eCG was administered to 28-day-old rats and ovaries and sera were collected $0,3,24,48,51,54,57,60$ and $72 \mathrm{~h}$ later. A 10 iu injection of human chorionic gonadotrophin (hCG) was administered $48 \mathrm{~h}$ after eCG. $n=6$ in each group except the 0 and $3 \mathrm{~h}$ groups ( $n=5$ and 3 , respectively). Bars with different letters are significantly different $(P<0.05)$ by Fisher's protected least significant difference test.

Table 1. Ovarian concentrations of tumour necrosis factor $\alpha$ in immature hypophysectomized rats injected with equine and human chorionic gonadotrophins

$\begin{array}{cc}\begin{array}{c}\text { Gonadotrophin-treated } \\ \text { immature rats }\end{array} & \begin{array}{c}\text { Saline-treated } \\ \text { immature rats }\end{array} \\ \text { (fg TNF- } \alpha \mu \mathrm{g}^{-1} \text { protein) } & \text { (fg TNF- } \alpha \mu \mathrm{g}^{-1} \text { protein) }\end{array}$

Day $28^{*}$

Day 29

Day 30

Day 31
$1.100 \pm 0.256(5)$

$\begin{array}{ll}0.027 \pm 0.007(6) & 0.972 \pm 0.175(6) \\ 0.097 \pm 0.017(6) & 1.230 \pm 0.409(7) \\ 0.026 \pm 0.036(6) & 0.894 \pm 0.071(6)\end{array}$

*Concentration in 28-day-old rats before injection with equine chorionic gonadotrophin (eCG) or saline. Animals were injected with human chorionic gonadotrophin $48 \mathrm{~h}$ after the eCG injection.

Numbers of animals are shown in parentheses.

in control animals (Sancho-Tello et al., 1993), indicating that the reduction in the number of ova shed is due to reduced numbers of developing follicles in response to eCG. Therefore, increased circulating concentrations of TNF- $\alpha$ suppress ovarian responses to exogenous gonadotrophins.

Similar observations have been made in vitro as evidenced by TNF- $\alpha$ suppression of FSH-induced aromatase in granulosa cells (Emoto and Baird, 1988) and TNF- $\alpha$ suppression of LH-stimulated thecal androgen synthesis (Andreani et al., 1991; Zachow et al., 1992). In addition, TNF- $\alpha$ has been shown to induce apoptosis of cultured early antral rat follicles (Kaipia et al., 1996). Elevated concentrations of TNF- $\alpha$ may reduce development of these follicles by inducing apoptosis. Therefore, it is possible that injection of eCG causes a decline in $\mathrm{TNF}-\alpha$ concentration, a reduction in apoptosis and development of follicules to the preovulatory phase. In contrast, TNF- $\alpha$ increases progesterone secretion by preovulatory follicles in vitro (Roby and Terranova, 1988, 1990; Brannstrom et al., 1993). In addition, TNF- $\alpha$ interacts synergistically with $\mathrm{LH}$ in inducing follicular rupture in vitro (Brannstrom et al., 1995). Therefore, TNF- $\alpha$ suppresses gonadotrophin-induced steroidogenesis, and suppresses differentiation or induces apoptosis in ovarian cells from developing follicles, whereas in preovulatory follicles, TNF- $\alpha$ promotes ovulation.

In the study of Sancho-Tello et al. (1993) the number of TNF- $\alpha$ immunoreactive cells (exclusive of the oocytes) increased 4 and $72 \mathrm{~h}$ after eCG injection. The increased number of TNF- $\alpha$ immunopositive cells $4 \mathrm{~h}$ after injection does not correlate with the observations of the present study in which bioactive TNF- $\alpha$ decreased $3 \mathrm{~h}$ after administration of eCG. The increase in TNF- $\alpha$-positive cells at $72 \mathrm{~h}$ compared with the $24 \mathrm{~h}$ time point observed by Sancho-Tello et al. (1993) is similar to the increase in bioactive TNF- $\alpha$ in the entire ovary. In addition, the number of TNF- $\alpha$-positive ceils before eCG injection is relatively low when compared with the other time points (Sancho-Tello et al., 1993). However, in the present study, bioactive TNF- $\alpha$ was highest before eCG injection $(\mathrm{O} \mathrm{h})$ relative to the other time points. The discrepancy in these results may be explained by the fact that TNF- $\alpha$-positive cells in the study of Sancho-Tello et al. (1993) did not include oocytic TNF- $\alpha$, whereas the bioassay used in the present study includes TNF- $\alpha$ from all cellular sources in the ovary. Alternatively, the expression of immunoreactive TNF- $\alpha$ may not correlate directly with the amount of bioactive TNF- $\alpha$. Regulation of TNF- $\alpha$ protein occurs by both posttranscriptional and post-translational mechanisms (Beutler et al., 1992). A recent study reported a reduction in TNF- $\alpha$ bioactivity at the same time as an increase in TNF- $\alpha$ immunoreactivity (Suffredini $e t$ al., 1995). This was due to the presence of a soluble receptor that inhibited TNF- $\alpha$ bioactivity but not TNF- $\alpha$ immunoreactivity. The presence and regulation of soluble TNF- $\alpha$ receptors and other factors such as the enzymic activation and inactivation of TNF- $\alpha$ in the ovary have not been investigated.

Ovarian and serum concentrations of TNF- $\alpha$ increased after administration of exogenous $\mathrm{hCG}$ during the preovulatory period. Several studies have suggested that TNF- $\alpha$ has a role in ovulation. Brannstrom ef al. (1995) reported that the addition of either LH or TNF- $\alpha$ to perfused ovaries induced ovulation of less than three ova per ovary, whereas a combination of LH and TNF- $\alpha$ induced ovulation of approximately II ova. TNF- $\alpha$ has been shown to increase the expression of leucocyte functional antigen-3 (LFA-3), a ligand of CD-2 antigen that is a 
surface marker of T-lymphocytes, in human granulosa cells in vitro (Hattori et al., 1995). Increased expression of LFA occurs in newly formed human corpora lutea (Hattori et al., 1995) suggesting that TNF- $\alpha$ is involved in increased expression of LFA-3 during ovulation. TNF- $\alpha$ increases prostaglandin synthesis during incubation of preovulatory follicles (Brannstrom et al., 1993) and prostaglandins have been implicated as causal factors in follicular rupture associated with the LH surge on pro-oestrus (Espey, 1994). In addition, TNF- $\alpha$ concentrations increase in follicular fluid during the bovine cycle as ovulation approaches (Zolti et al., 1990). In the present study, serum TNF- $\alpha$ concentrations during the first natural ovulation remained low and did not change until day 43 . Serum TNF- $\alpha$ concentrations measured at day 43 were comparable to the concentrations after hCG administration in the induction of ovulation. This natural increase in serum TNF- $\alpha$ may be related to an endogenous surge of LH. It has been demonstrated that nearly all cell types have the capacity to produce TNF- $\alpha$. Therefore, an increase in serum TNF- $\alpha$ concentrations at the first ovulation may also represent development or maturation of other cellular systems.

In summary, high TNF- $\alpha$ concentrations were present in the ovary of immature rats. Treatment with eCG rapidly decreased ovarian TNF- $\alpha$ concentrations in immature rat ovaries without alteration of serum TNF- $\alpha$ concentrations. Similarly, ovarian TNF- $\alpha$ concentrations decreased in pubertal rats after the first ovulation. However, ovarian and serum concentrations of TNF- $\alpha$ increased during the preovulatory period after administration of an ovulation-inducing injection of hCG. These results suggest that TNF- $\alpha$ is involved in follicular development and ovulation at puberty and in immature rats in which ovulation has been induced with gonadotrophins.

This work was supported by grants from the National Cancer Institute (CA50616) to P. F. Terranova and V. Montgomery Rice. The research was performed within the Center for Reproductive Sciences supported by the National Institute of Child Health and Human Development (NIHHD 33994).

\section{References}

Andreani CL, Payne DW, Packman JN, Resnick CE, Hurwitz A and Adashi EY (1991) Cytokine-mediated regulation of ovarian function. Tumour necrosis factor $\alpha$ inhibits gonadotropin-supported ovarian androgen biosynthesis Journal of Biological Chemistry 266 6761-6766

Beutler B, Han J, Kruys V and Giroir BP (1992) Coordinate regulation of TNF biosynthesis at the levels of transcription and translation. In Tumour Necrosis Facfors: The Molecules and Their Emerging Role in Medicine pp 56I-574 Ed. B Beutler. Raven Press, New York

Bradford M (1976) A rapid and sensitive method for the quantitation of microgram quantities of protein utilizing the principle of protein-dye binding Analytical Biochemistry 72 248-254

Brannstrom M, Wang LJ and Norman RJ (1993) Effects of cytokines on prostaglandin production and steroidogenesis of incubated preovulatory follicles of the rat Biology of Reproduction 48 165-171
Brannstrom M, Norman RJ, Seamark RF and Robertson SA (1994) Rat ovary produces cytokines during ovulation Biology of Reproduction 50 88-94

Brannstrom M, Bonello N, Wang LJ and Norman RJ (1995) Effects of tumour necrosis factor $\alpha(\mathrm{TNF} \alpha)$ on ovulation in the rat ovary Reproduction Fertility and Development 7 67-73

Doherty GM, Jensen JC, Alexander HR, Buresh CM and Norton JA (1991) Pentoxifylline suppression of tumour necrosis factor gene transcription Surgery 110 192-198

Emoto $\mathrm{N}$ and Baird A (1988) The effect of tumour necrosis factor/cachectin on follicle stimulating hormone-induced aromatase activity in cultured rat granulosa cells Biochemical and Biophysical Research Communications 153 $792-798$

Espey LL (1994) Current status of the hypothesis that mammalian ovulation is comparable to an inflammatory reaction Biology of Reproduction 50 233-238

Hattori N, Ueda M, Fujiwara H, Fukuoka M, Maeda M and Mori T (1995) Human luteal cells express leukocyte functional antigen (LFA-3) Journal of Clinical Endocrinology and Metabolism 80 78-84

Hehnke-Vagnoni KE, Clark CL, Taylor MJ and Ford SP (1995) Presence and localization of tumour necrosis factor- $\alpha$ in the corpus luteum of nonpregnant and pregnant pigs Biology of Reproduction 53 1339-1344

Ji I, Slaughter RG, Ellis JA, Ji TH and Murdoch WJ (1991) Analyses of ovine corpora lutea for tumour necrosis factor mRNA and bioactivity during prostaglandin-induced luteolysis Molecular and Cellular Endocrinology 81 $77-80$

Kaipia A, Chun S- $X$, Eisenhauer K and Hsueh AJW (1996) Tumour necrosis factor $\alpha$ and its second messenger, ceramide, stimulate apoptosis in cultured ovarian follicles Endocrinology $1374864-4870$

Marcinkiewicz JL, Krishna A, Cheung C and Terranova PF (1994) Oocytic tumour necrosis factor $\alpha$ : localization in the neonatal ovary and throughout follicular development in the adult rat Biology of Reproduction 50 125 I-1260

Mosmann T (1983) Rapid colorimetric assay for cellular growth and survival: application to proliferation and cytotoxicity assays Journal of Immunological Methods 65 55-63

Richards JS (1980) Maturation of ovarian follicles: actions and interactions of pituitary and ovarian hormones on follicle cell differentiation Physiological Reviews 60 51-89

Roby KF and Terranova PF (1988) Tumour necrosis factor $\alpha$ alters follicular steroidogenesis in vitro. Endocrinology 123 2952-2954

Roby KF and Terranova PF (1990) Effects of tumour necrosis factor $\alpha$ in vitro on steroidogenesis of healthy and atretic follicles of the rat: theca as a target Endocrinology 126 2711-2718

Sancho-Tello M, Tash JS, Roby KF and Terranova PF (1993) Effects of lipopolysaccharide on ovarian function in the pregnant mare serum gonadotropin-treated immature rat Endocrine Journal 1 503-512

Shaw DW and Britt JH (1995) Concentrations of tumour necrosis factor $\alpha$ and progesterone within the bovine corpus luteum sampled by continuous-flow microdialysis during luteolysis in vivo. Biology of Reproduction 53 847-854

Suffredini AF, Reda D, Banks SM, Tropea M, Agosti JM and Miller R (1995) Effects of recombinant dimeric TNF receptor on human inflammatory responses following intravenous endotoxin administration Journal of Immunology 155 5038-5045

Terranova PF, Hunter VJ, Roby KF and Hunt JS (1995) Tumour necrosis factor $\alpha$ in the female reproductive tract Proceedings of the Society for Experimental Biology and Medicine 209 325-342

Wuttke W, Jarry H, Pitzel L, Knoke I and Spies S (1993) Luteotrophic and luteolytic actions of ovarian peptides Human Reproduction 8 141-146

Zachow RJ, Tash JS and Terranova PF (1992) Tumour necrosis factor a induces clustering in ovarian theca-interstitial cells in vitro. Endocrinology 131 $2503-2513$

Zolti M, Meirom R, Shemesh M, Wollach D, Mashiach S, Shore L and Ben Rafael $\mathrm{Z}$ (1990) Granulosa cells as a source and target organ for tumour necrosis factor $\alpha$ FEBS Letters $261 \quad 253-255$ 